\title{
Adenocarcinoma with Spindle Cell Metaplasia
}

National Cancer Institute

\section{Source}

National Cancer Institute. Adenocarcinoma with Spindle Cell Metaplasia. NCI Thesaurus. Code C4201.

An invasive adenocarcinoma characterized by focal or extensive transformation of the malignant glandular cells to spindle-shaped cells. 